\title{
The Internet Will Drive Corporate Monitoring
}

\author{
Mark Latham \\ First draft: February 28, 1999; this draft: October 22, 1999 \\ Published in Corporate Governance International, June 2000
}

\begin{abstract}
Using the internet for shareowner proxy voting will not just save money. It will awaken the sleeping giant of corporate governance -- individual investors. It will give shareowners unprecedented influence over the policies of large corporations, by making "corporate monitoring" possible. Rational voter apathy will be counteracted by the internet's ability to make information exchange cheap and easy. Likely benefits include higher profits, support for social goals, and more realistic levels of CEO pay. Compared to other countries, America has more stock held by individuals who use the internet, so America will lead this trend.
\end{abstract}

Mark Latham is a financial economist and consultant. Contact by e-mail:

mlatham@corpmon.com; phone: (415) 391-7198; fax: (415) 680-1521; or post: 10 Miller Place \#1701, San Francisco, CA 94108, USA. See www.corpmon.com for future versions of this paper, discussion and further information on corporate monitoring. I gratefully acknowledge helpful comments from Mark Rubinstein and Gregory Maassen. A French translation of this article is forthcoming in Gouvernance Revue Internationale. 


\section{Introduction}

Managers of large corporations sometimes do not act in the best interests of their employers, the shareowners. This problem has troubled economists and business people for centuries, and although progress has been made, the agency costs of this conflict of interests remain substantial. ${ }^{1}$ Especially when no shareowner owns more than, say, $5 \%$ of the firm, no one has enough incentive to monitor management, because the private benefit is small - the "free rider" problem.

To remedy this, Baums and von Randow (1995) proposed a system of "voting agents" entrepreneurs who would compete to be chosen by shareowners to vote shares on their behalf. These agents would be paid by the firm and thus by all shareowners, so as to minimize the "free rider" effect. A large firm would have up to three voting agents at a time, each voting a portion of the shares depending on shareowner votes received.

A similar proposal was made by Latham $(1998,1999 a)$, but with only one, more powerful agent per client firm. This agent, called a "corporate monitoring firm" (CMF), would have access to inside information and would select candidates for the board of directors. In a more modest proposal, Latham (1999b) suggested modifying the role now played by proxy advisory firms, paying them via the company being monitored, as determined by shareowner vote. Proxy advisory firms could then evolve gradually into corporate monitoring firms.

Baums and von Randow looked to the German government to enact their proposal, but the ruling party seems unlikely to pass such a law. Latham aims to convince institutional shareowners to muster a majority vote in the face of likely management opposition; that effort is just beginning.

This paper explores a third avenue for initiating such systems: using the internet to mobilize support from individual investors. Although rational voter apathy should be especially prevalent among small investors, the power of the internet for exchanging information cheaply will be an effective antidote. The voting agent industry will then grow from a loss-making provider of freeware to a profitable and powerful component of the online securities world.

\section{Proxy Voting on the Internet}

Investors can already vote proxies on the web, at www.proxyvote.com. The site was launched in 1998 by ADP (Automatic Data Processing), the firm that manages distribution of mailed hard-copy proxies for most large U.S. corporations. Most corporations have yet to sign up for the new system, but it is expected to become 
widespread in the next few years. A similar service from EquiServe LP is at www.voteby-net.com. What will be the impact of voting proxies via the internet?

Suppose you own shares in twenty companies. Every year, you have been getting twenty envelopes in the mail with proxy forms to fill in and mail back. The forms asked you to vote on directors and proposals. You looked at them, didn't know what to vote for, stuck them on a pile to think about later, and after six months threw them out. But felt a bit guilty about it. Now, you will get twenty proxy ID numbers, go to www.proxyvote.com, enter in a number, see the items to vote on, not know what to vote for, and give that up too.

But things can and will be made even easier for you. You may have noticed on those proxy forms that you can check a box to vote for management's recommendations. The web page has a similar box. That has always been the simplest option, to delegate your decision to management. They know best, and who has time to think about it?

Soon you will be able to click a management check-box just once, and some software will take care of the rest. It will log in to www.proxyvote.com, transmit your proxy ID numbers, and vote each stock following management's recommendations. This automatic voting capability will probably be a new feature of financial management software like Quicken, ${ }^{2}$ which already can connect to financial institutions and get detailed information about your holdings of individual stocks.

If you don't want to leave all decisions up to management, you can click down through the software, read the items to be voted on, make your own decisions, then click "Transmit" to send to www.proxyvote.com. You might choose to just override management on a couple of points, but vote with them on the rest.

However, neither of these two options is entirely desirable. Management should not be trusted blindly, but you lack the time and knowledge to judge for yourself. Wouldn't it be helpful if Quicken had another check-box that would vote all your stocks following the advice of a group of experts that you trust? For example, there already are proxy advisory firms paid by pension and mutual funds to advise them on voting their shareholdings. Proxy Monitor and Institutional Shareholder Services are two such advisors. Their full-time staffs study all proposals put to shareowner vote at thousands of corporations around the world.

Imagine for now that they make their recommendations available to individual investors for free on the web. They each maintain a web site listing all companies they cover, and showing their recommendation on how shareowners should vote each item. To make it easy for you to vote, Quicken then has a "Proxy Monitor" check-box and an "Institutional Shareholder Services" check-box as well as the "Management" check-box. Now you have a real choice without it being much trouble for you. You happened to see an article in the Wall Street Journal praising Proxy Monitor, so you check that box, connect to the internet, and click "Transmit". Quicken connects to the Proxy Monitor website, gets the recommendations for the stocks you own, then connects to www.proxyvote.com and sends in your votes. 
If you like to keep it as simple as possible, you just leave the Proxy Monitor box checked indefinitely. Perhaps once a week, Quicken automatically checks whether there are new proxies to vote for any stocks you hold, gets the Proxy Monitor recommendations, and sends in your vote. Months later, if you happen to hear about a better advisory firm, you open up Quicken and select that one instead.

If you want to override the advisory firm's recommendation on any particular issue, you set an option in Quicken to ask for your confirmation before transmitting your votes to www.proxyvote.com. Then you click down through Quicken to read that item (director choice or proposal), read it, enter your decision, and click Transmit.

\section{Voting Advice - Freeware}

In the arrangement just described, the proxy advisory firms are unpaid. Before we discuss whether and how to pay them, let's list a few more candidates that some shareowners might choose to give them voting advice, starting with the two already mentioned:

1. Management of the firm whose stock you are voting.

2. A proxy advisory firm.

3. A mutual or pension fund's proxy voting department. For example, you might want to vote the same way as leading governance activist funds like CalPERS and LENS. Such information is already becoming available on the web - see www.corpmon.com/Vote.htm

4. Your stock broker.

5. A security analyst with a strong reputation for the industry of the firm whose stock you are voting.

6. Your favorite business journalist.

7. An environmental group, like the Sierra Club or Greenpeace.

8. A "social investment" advocate.

9. A "meta-advisor", who would pass through voting advice from one or more sources. For example, the source could be chosen contingent on industry, or it could be an average with weights chosen by you or by the meta-advisor.

Each advisor would maintain a website showing its voting recommendations. With so many possible advisors popping up all the time, instead of Quicken having a click-box for each one it would be more practical to have, for example, a box where you enter your chosen advisor's web address (URL). You could retain the option of not following their advice on any particular vote that you want to judge for yourself. But if you prefer to 
keep things very simple, you could just choose one advisor, enter its address and be done with it.

\section{Voting Advice - Professional}

There is some excellent freeware out there, but sometimes you get what you pay for. It takes time and expertise to do the best job of deciding how to vote. Surely shareholders could get better voting advice by paying for it, the way institutional investors pay proxy advisory firms now. Because of the free-rider problem however, no individual investor wants to pay.

Instead, the corporation could pay one or more sources to advise shareowners on voting its proposals. The advisors to be paid are themselves chosen by shareowner vote.

Each advisor announces its fee in advance; if shareholders find a fee too high, they vote for someone else. ${ }^{3}$ Note that the voting to decide whether to adopt this system, and the voting to choose advisors, would no doubt also be conducted with input from advisors. ${ }^{4}$ So shareowners who don't want to think about this multi-stage process wouldn't have to. They can just choose an advisor as described in the previous sections, and the rest would happen automatically if a majority of votes are cast in favor.

Demand and competition will induce evolution of advisors that are increasingly appealing to shareowners.

\section{Proactive Agents - Corporate Monitoring}

Advising intelligently on corporate policy proposals is valuable, but merely reactive, a response to proposals made. Who conceives and puts forward these proposals, and to what ends? In practice, some are put forward by management, and some by shareholders.

Professional advisors chosen by competitive shareowner vote, and paid by the corporation, would presumably be trustworthy and capable. Why not empower them to make proposals? The same arguments can be made for this as for advising: it adds value to the firm, it may be neglected by management because their interests differ from those of the owners, and the free-rider problem makes shareowners unlikely to undertake the work required to devise the best proposals. The bylaw change to grant this power to a the shareowners' chosen professional agent would itself be accomplished by a shareowner proposal.

Nomination of directors fits this same description. Shareowners will benefit if professional agents nominate directors also. In fact, professional oversight of the director selection process may be necessary to prevent a loss of board collegiality that could result from the free-for-all of competitive elections. Once we start voting for directors on the web, the inevitable development of freeware advisors will make it easy 
for opposing candidates to compete for board seats. Most observers agree that a successful firm needs a board of directors that works as a team and has complementary skills. The top vote-getters in a competitive election may lack these desirable features.

How can shareowners have board candidates competing to serve their interests, and still end up with a cohesive effective board? One way is to specify a "lead" agent, who may be the only agent paid by the client firm in a given year, or perhaps the agent that gets paid the most. ${ }^{5}$ The lead agent would be responsible for nominating a coherent board slate. There would still be open elections for the board, but the lead agent's slate would probably win.

Perhaps such a "lead slate" arrangement would happen naturally without a lead agent system. Even freeware advisors could recognize the value of collegiality, and somehow converge on one cohesive board slate. Time will tell. At the other extreme, our enduring capacity for disagreement could disrupt even a lead agent's slate, in which case shareholders may benefit from more restrictive board election rules.

Once shareowners gain confidence in this system, they can enhance it by giving the lead agent access to information inside the client firm. Especially when deciding whether to renominate an incumbent director, confidential evaluations by fellow directors and a review of board meeting minutes would be invaluable. An agent performing this degree of monitoring can be called a corporate monitoring firm (CMF).

Would CMFs be too powerful? If this system spreads to most large firms, standards could be adopted to prevent the same CMF from monitoring two firms in the same industry. But remember that CMFs can only become powerful to the extent that they keep the trust of shareowners, since they are chosen by shareowner vote. There is a tradeoff in determining the ideal number of CMFs in such a system. To prevent overconcentration of power, more is better; to keep the voting decision simple, fewer is better. However, we can have our cake and eat it too by using meta-advisors.

Shareowners who want to keep their decisions as simple as possible can choose among a few competing meta-advisors. Each meta-advisor can recommend which of the many CMFs should monitor which company, and internet software can automatically vote your stock accordingly.

\section{The Danger of Vote-Selling}

Perhaps the greatest danger of proxy voting on the internet is the temptation for shareholders to cheaply sell their votes. For the same reason that a rationally selfish small shareholder wouldn't pay for voting advice, he would gladly accept 5 cents a share to let the payer determine how to vote his stock. The same software integration that makes choosing a voting advisor easy could make selling your votes easy too. Worse, the two could be subtly blended, with a vote buyer masquerading as an advisor, embedding little bribes in their advertising somehow. This may enable the CEO to buy $51 \%$ of the votes, and shareowners would lose control of the firm again. 
Shareowners therefore benefit as a group from prohibiting vote-selling. Legal enforcement of this provision is necessary for effective corporate governance. Just as vote-selling is deterred in political elections by keeping ballotting secret, it can be deterred in a voting advisor system by outlawing the actual delegation of voting to an agent. Instead, advice must be transmitted to the voter's computer, which in turn casts the actual vote without confirming back to the source which way it voted.

\section{Passing Through Voting Rights}

Institutional investors - mutual and pension funds - hold about $60 \%$ of the equity of large U.S. corporations. Individuals hold the other $40 \%$.

The data systems enabling individual investors to vote stock on the net could be expanded to allow them to vote stock that they beneficially own through mutual and pension funds. Mutual funds are easier because the calculation of who owns what is based on simple proportions. Pension funds are harder because actuarial estimates of lifespan and future incomes are involved. But those estimates are calculated regularly already, and since we are just talking about allocating votes here, not money, a little inaccuracy is not a serious problem.

More difficult still is the question of who should vote the stock in "defined benefit" pension funds. Gains and losses of such funds primarily affect the wealth of the sponsor corporation's shareowners rather than the pension beneficiaries. So it makes more sense to pass through the votes to those shareowners.

Similarly, companies that own stock in other companies could pass those voting rights through to their own shareholders, on a pro rata basis like a mutual fund. There is very little such cross-holding in the U.S., but for many other countries like Japan and Korea this would be a huge shift in voting power. ${ }^{6}$

So now we are talking about potentially $100 \%$ of the stock, not just $40 \%$. Of course, it will take many years to approach $100 \%$, and meanwhile the new system will complement the old.

\section{Is Corporate Democracy Really Imminent?}

This article may at first sound like a far-fetched plan with little chance of gaining the widespread support needed to make it happen. But in fact the opposite is true: it will happen so automatically that it will be all but impossible to prevent. Just put your company's proxy voting on the web, and the game is over.

Very little motivation and knowledge are required from individual investors. First of all, a shareowner can just leave her software with the default settings: let company management vote the shares she holds directly, and let the fund managers vote the 
shares she owns through mutual and pension funds. To see what it would take for her to change those settings, compare it with voting in political elections. It would be much less trouble, since the settings could be changed from her computer at any convenient time by clicking the mouse. As with politics, there would be no shortage of expert opinion and endorsements in the media as to which option to set. She could scarcely avoid forming an opinion.

American politics now is reasonably democratic, and in a kind of dynamic equilibrium of various forces. By contrast, when it comes to voting stock, individual investors are essentially disenfranchised. When they get the vote, the resultant realignment of power will add to the excitement we already have about stocks and the internet. We can anticipate voter participation well in excess of that in political elections.

It will not be hard to recommend better choices than the status quo. Why are there laws requiring institutional investors to vote their stock rather than leaving everything up to management? Management has well known conflicts of interest. A better choice could involve just a single mouse-click, choosing one recommended advisor instead of management. That would be enough to shift power dramatically.

Would you outlaw software that makes voting easy? Would you outlaw advice? The only justifiable grounds for restriction would be vote-selling, but that can be prevented without outlawing advice and helpful software. Even if advisors weren't permitted to put forward proposals or nominate directors, they could easily find a shareowner to front for them.

As for passing through votes, mutual funds could offer this as an option. Some shareholders would want it. On what grounds should it be outlawed? Defined contribution pension funds are like mutual funds, and may behave similarly. Defined benefit pension funds are like corporate cross-holdings, and may be more difficult to pass through if management opposes it. But if that is the last holdout, the conflict of interest would be flagrant: management would clearly be acting in direct opposition to the owners' wishes and interests. Such opposition could only survive behind the fortifications of much greater cross-holdings than are prevalent in the U.S., combined with the complicity of an undemocratic legislature.

The voting agency and software developments outlined here would start with no revenue, but promise to be profitable later - the standard internet business model. Software developers have an incentive to add this feature, and would-be advisors have an incentive to start creating their recommendation sites.

How much can this system accomplish even for firms that drag their feet and delay going on-web? Advisors could still put up their recommendations. Armed with those, many shareowners would be willing to vote by mailing a paper ballot. Most shareowners say the reason they don't vote is not the paperwork, but the lack of knowledge about which way they should vote. Investors in mutual funds could still transmit their votes electronically to the fund, which could pass those on. The automation of institutional investor voting has progressed much further than for individual investors. 


\section{Legal Hurdles}

The shareowner voting process required to hire professional advisors (described in section 4 above) must be kept independent of management. The usual shareowner proposal process enacts precatory proposals, leaving the board discretion as to whether to obey them. It may thus be necessary to use a binding bylaw amendment. These are overseen by state law, and the degree to which shareowners can enact such amendments in the face of management opposition is being debated in Delaware, where most large U.S. firms are incorporated. There may be significant legal obstacles to proposals authorizing expenditures without review by the board of directors, as discussed in Hamermesh (1998). It would be unfortunate if such a law were to block the creation of a mechanism beneficial to investors and the economy as a whole. Possible remedies include revision of the law, and incorporation in another state.

Hamermesh points out that shareowner proposals have only recently become popular, the legal rules have not yet been clearly delineated, and there are reasons to suspect that allowing broader use of this tool may actually harm investors. Given rational voter apathy induced by the free-rider problem, a small group of investors may try to use the proposal mechanism to advance their interests at the expense of the majority, by greenmail or other means. As amateur attempts to usurp professional managerial authority, resolutions may be poorly written, confusing, and in conflict with each other.

While these problems may hamper some proposals, they are actually arguments in favor of the type of proposal advocated in this paper. Having the company pay for proxy advice for all shareholders removes most of the free-rider problem, making it easier for all investors to vote intelligently, diminishing the clout of activist minorities with diverging interests. As suggested in section 4 above, an advisory firm can help write future proposals, bringing greater professionalism to that process. Thus investors can have both "voice" and "exit". Even those with small holdings and short holding periods can vote meaningfully with minimal effort, based only on the reputations of competing advisory firms.

\section{Costs and Benefits}

The costs of bulding the information infrastructure needed for a voting advisor system are significant, but small relative to benefits of improving corporate policies. Money will be saved by reducing paper mailings. Fees paid to professional advisors and agents will be offset by reduced payments to directors, management, and consultants, because the new agents will be fulfilling some of their functions.

Potential benefits of corporate monitoring are discussed extensively in Latham (1998, 1999a). They include higher profitability, less short-termism, more realistic levels of 
CEO pay, and a balancing of profit with social goals. These are all consequences of having the firm managed in the owners' interests.

Yet how could a cacophony of agents make a company better managed than the full-time professionals now on the board? I am perhaps making the optimistic assumption that the consensus of shareowners will have the sense not to take this new weapon and shoot itself in the collective foot. But remember, this is the same consensus that has made the stock market so efficient that it can only be beaten by Warren Buffett and the occasional typewriting monkey.

Should we subject our great corporations, locomotives of the economic gravy train, to the turbulent cycles of popular fashion and passion? Or, to change transportation modes, how can you drive a car with so many hands pulling the steering wheel in different directions? It sounds like a CEO's worst nightmare. But it isn't. Crashing the firm into a ditch is not in the owners' interests, and the voting advisor system is designed to further those interests. There will still be a single CEO driving.

This is fundamentally about individuals asserting their property rights. By allowing the public to protect its own interests, the government can stay out of managing corporations. There will be less need for shareholder lawsuits, because shareholders will no longer be powerless.

\section{Conclusion}

The internet is bringing a corporate governance revolution that is virtually unstoppable. Investors will gain influence over management, and the results will be widely beneficial. Both profits and social goals will be enhanced. Broad participation in determining the policies of large firms will make people more comfortable with the pervasive role of business in our society. We will soon witness a period of accelerated evolution by trial and error, and competition among participants and modes of corporate oversight. The transition will proceed by new information systems developing, investors learning how to use them, voting advisors gaining expertise, and old laws changing. The division of power and functions among shareowners, directors, management, and other shareowner agents will be revamped.

The resulting framework for aggregating information, opinions and preferences on the internet may also prove useful in other applications, such as politics. 


\section{Endnotes}

1. There are many surveys on this subject. See, for example, Monks and Minow (1996).

2. Quicken is a registered trademark of Intuit Inc.

3. There are other feasible ways to determine the advisor's fee, but management should not be allowed to influence it, since they would prefer to minimize monitoring.

4. Advisors would probably recommend voting for themselves, and there's nothing wrong with that -- call it bootstrapping.

5. As discussed in Latham $(1998,1999 a)$, vote-splitting can be a problem when choosing a single agent, and preferential voting can solve this. Instead of voting for just one candidate (or two or three), each shareowner gives a ranking of all candidates and a computer finds the most preferred one(s), essentially performing runoff elections automatically. A shareowner wishing to keep his voting procedure as simple as possible could instead just choose one meta-advisor, who would do the required ranking. A full-service meta-advisor could do this for all stocks indefinitely, updating its rankings as agent reputations change, so that one mouse-click could take care of an investor's voting forever.

6. Multiple layers of firms that own stock in firms that own stock in etc. can make the pass-through calculations more complex, but computers are good at that.

\section{References}

Baums, Theodor, and Phillip von Randow (1995): "Shareholder Voting and Corporate Governance: The German Experience and a New Approach," in Corporate Governance in Transitional Economies, edited by Masahiko Aoki and Hyung-Ki Kim; The World Bank.

Hamermesh, Lawrence A. (1998): "Corporate Democracy and Stockholder-Adopted ByLaws: Taking Back the Street?" Tulane Law Review 73:2 (December).

Latham, Mark (1998): "Corporate Monitoring: New Shareholder Power Tool," Financial Analysts Journal 54:5 (September/October).

Latham, Mark (1999a): "The Corporate Monitoring Firm," Corporate Governance - An International Review 7:1 (January); http://www.corpmon.com/CorpMonFirm.htm .

Latham, Mark (1999b): "Collective Action for Dispersed Shareowners," Corporate Governance International (September); http://www.corpmon.com/CollAct.htm .

Monks, Robert A. G., and Nell Minow (1996): Watching the Watchers, Blackwell Publishers. 